\title{
Medical therapy for advanced gastro-entero-pancreatic and bronchopulmonary neuroendocrine tumors
}

\author{
Mariangela Torniai', Silvia Rinaldi', Francesca Morgese ${ }^{1}$, Giulia Ricci', Azzurra Onofri', Christian Grohé2 \\ Rossana Berardi ${ }^{1}$ \\ ${ }^{1}$ Department of Medical Oncology, Università Politecnica delle Marche, 60100 Ancona, Italy. \\ ${ }^{2}$ Department of Respiratory Diseases, Ev. Lungenklinik Berlin, Universitätsmedizin Charite, Lindenberger Weg 27, 13125 Berlin, Germany
}

Corresponding Author: Prof. Rossana Berardi, Medical Oncology Unit, Università Politecnica delle Marche, Azienda Ospedaliero-Universitaria Ospedali Riuniti Umberto I, GM Lancisi, G Salesi di Ancona, Via Conca 71, 60126 Ancona, Italy. E-mail: r.berardi@univpm.it

\section{A B S T R A C T}

Neuroendocrine tumors (NETs) represent a spectrum of rare neoplasms arising in different organism sites. Depending on the site of onset, they also can be distinguished using lab exams (secreting vs. nonsecreting), clinical symptoms (functioning vs. nonfunctioning), behavioral, morphological characteristics (tumor cells' architectural growth patterns, mitotic and Ki-67 index, presence of necrosis), and grade of cellular differentiation. The aim of this review is to focus on the main signaling pathways targeted by medical treatments of advanced sporadic gastro-entero-pancreatic (GEP) and bronchopulmonary (BP) neuroendocrine neoplasms. The scientific literature regarding treatment of advanced GEP and BP-NETs has been extensively reviewed using MEDLINE and PubMed databases, selecting principal and more recent research articles, clinical trials, and updated guidelines. Somatostatin analogues represent a valid approach to control symptoms in functioning tumors and to inhibit tumor progression in certain categories on the basis of the typical somatostatin receptor expression observed in NETs. The pathogenesis of NETs has been the subject of increased interest in recent years. Many driver mutations pathway genes have been identified as important factors in the carcinogenesis process and, therefore, as potential targets for new anticancer therapies. Activating mutations have been shown in epidermal growth factor receptor, stem cell factor receptor, platelet-derived growth factor receptor, vascular endothelial growth factor, basic-fibroblastic growth factor, transforming growth factor, insulin-like growth factor-1, and their receptors. Effective M-Tor inhibition pathway modulation has led to the approval of drugs in this field such as everolimus. New drugs and several combination regimens with targeted and newer biological agents are being developed and tested in recently conducted and ongoing trials.

Key words: Gastrointestinal and bronchopulmonary neuroendocrine tumors; advanced disease; medical treatment; targeted agents

\section{INTRODUCTION}

Neuroendocrine neoplasms typically occur in gastrointestinal and bronchopulmonary tracts. Gastroentero-pancreatic neuroendocrine neoplasms (GEPNENs) originate from neuroendocrine cells of the gastrointestinal tract and pancreatic islets. ${ }^{[1]}$

Three-tiered grading systems have been proposed for GEP-NENs classification, according to their morphological features and ki-67 index: ${ }^{[2]}$ neuroendocrine tumors (NETs), involving G1 (ki67<3\%) and G2 (ki67 $\geq$ 3 and $\leq 20 \%$ ) neoplasms, and neuroendocrine carcinomas, G3 with ki67 > 20\%. Neuroendocrine carcinomas show worse prognosis, and platinum-based chemotherapy is currently considered the standard of care..$^{[3,4]}$

\begin{tabular}{|l|l|}
\hline \multicolumn{2}{|c|}{ Access this article online } \\
\hline Quick Response Code: & Website: \\
\hline & www.jcmtjournal.com \\
\cline { 2 - 3 } & \\
\hline
\end{tabular}

Identification of many driver mutations in pathway genes involved in the pathogenesis of well- and moderatelydifferentiated NENs has promoted the development of specific targeted therapies. ${ }^{[5-7]}$

Conversely, bronchopulmonary NETs are approximately $20-25 \%$ of all lung malignancies. ${ }^{[8-12]}$ On the basis of 2004, World Health Organization classification, pulmonary NETs can be divided into three groups: ${ }^{[13]}$ carcinoid tumors (typical carcinoids/atypical carcinoids) (1-2\%), large-cell neuroendocrine (LCNEC) (3\%), and small-cell carcinomas (SCLC) (15-20\%). According to immunohistochemical markers, these neuroendocrine

This is an open access article distributed under the terms of the Creative Commons Attribution-NonCommercial-ShareAlike 3.0 License, which allows others to remix, tweak, and build upon the work non-commercially, as long as the author is credited and the new creations are licensed under the identical terms.

For reprints contact: service@oaepublish.com

How to cite this article: Torniai M, Rinaldi R, Morgese F, Ricci G, Onofri A, Ghroé C, Berardi R. Medical therapy for advanced gastroentero-pancreatic and bronchopulmonary neuroendocrine tumors $\mathrm{J}$ Cancer Metastasis Treat 2016;2:329-40.

Received: 28-07-2016; Accepted: 15-08-2016 
entities are further summarized into 2 groups based on their grade of biological aggressiveness: welldifferentiated neoplasms including typical and atypical carcinoids, and poorly differentiated ones involving LCNEC and SCLC.

Despite comprehensive and notable medical progress, therapeutic options are still inadequate for gastrointestinal and bronchopulmonary (BP) neuroendocrine tumors, due to the lack of in-depth knowledge of molecular mechanisms and predictive factors. This review aims to summarize the current knowledge about pathways involved in advanced, sporadic well- and moderately differentiated GEP-NETs and in BP carcinoids, highlighting available evidences on biological and targeted therapies.

\section{SHORT SYNTHETIC ANALOGUES OF SOMATOSTATIN}

The primary treatment objective for patients with NETs is cure. Symptom control and limitation of disease progression represent the secondary goals. The traditional first and only possible radical approach is surgery. However, NETs are frequently diagnosed in advanced stages when curative surgery is generally not possible. Medical management with the principal objective of relieving symptoms and, in recent years, of suppressing tumor growth and spread is a necessary option for advanced NETs that are unsuitable for surgery. ${ }^{[14]}$

Among medical therapies, Short synthetic analogues of somatostatin (SSAs) represent one of the possible options in the presence of carcinoid syndrome. SSAs include octreotide, lanreotide, vapreotide, seglitide, and pasireotide. SSAs' affinity for the distinct receptor subtypes is different than that of native somatostatin. ${ }^{[15-17]}$ Five different somatostatin receptor (SSTR) subtypes have been characterized in humans (SSTR1-SSTR5) [Figure 1]. ${ }^{[18-22]}$ SSTR2 represents the principal target for octreotide, lanreotide, vapreotide, seglitide, and pasireotide. Furthermore, pasireotide shows a higher binding capacity towards SSTR1, activating also SSTR 3 and 5. ${ }^{[23-25]}$ For this reason, different SSAs show a distinct affinity with their own ligands, eliciting various biological and clinical activities ${ }^{[16]}$ in the same cell type through the activation of subsets of disparate intracellular mediators. ${ }^{[23,24,26]}$ Nevertheless, the natural ligands of SSTR1-5 can bind all somatostatin receptors with high affinity.

SSTRs were expressed in over $80 \%$ of well-differentiated GEP-NENs. SSTR in particular has been observed to predominate in both gastrointestinal-NENs $(90 \%)$ and primitive-NETs (P-NETs), especially in gastrinomas,

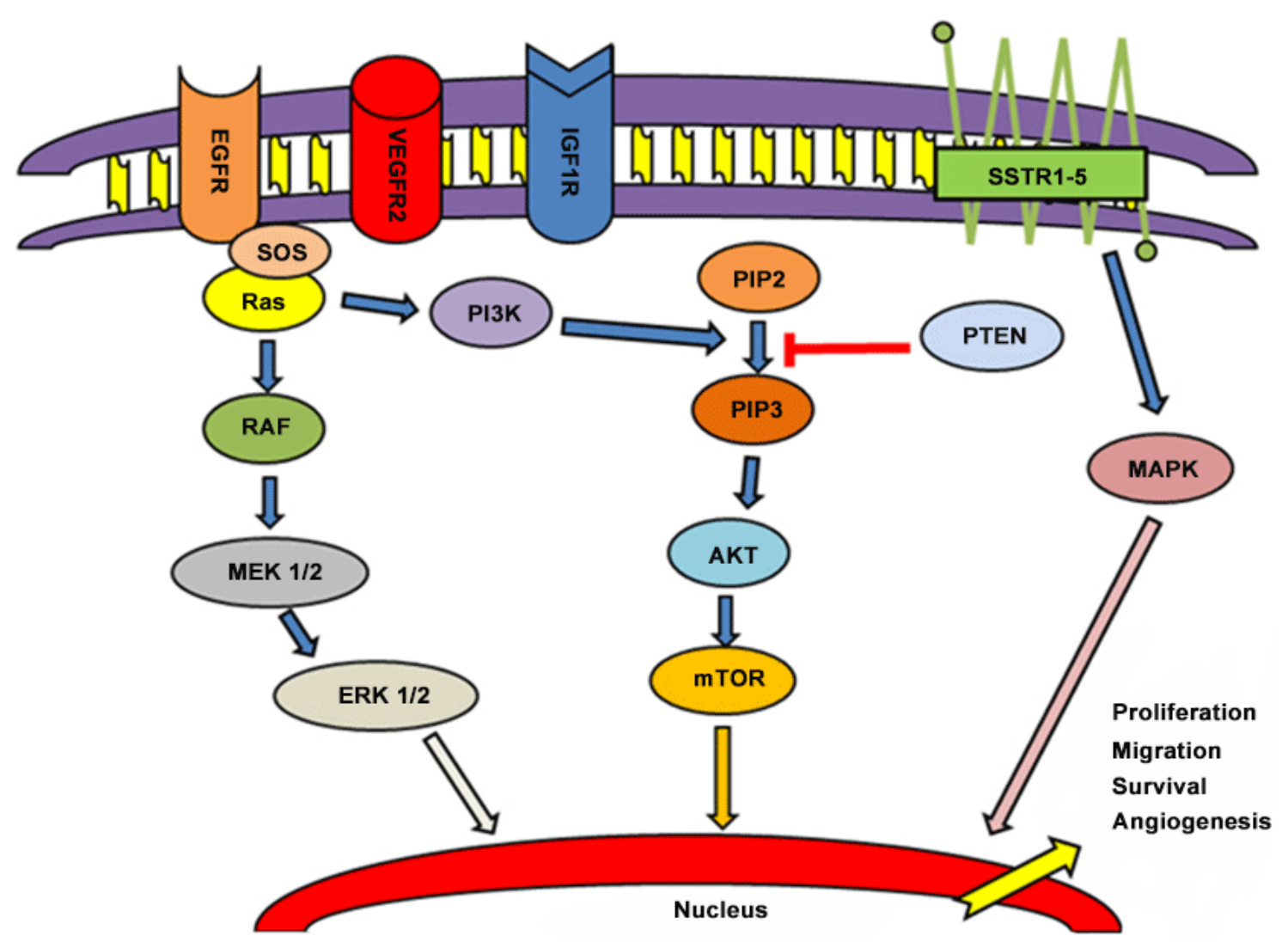

Figure 1: Principal pathways involved in carcinogenesis and progression of NENs. EGFR: epidermal growth factor receptor; VEGFR2: vascular endothelial growth factor receptor 2; IGF1R: insulin-like growth factor 1 receptor; SSTR: somatostatin receptors; SOS: save our souls; PI3K: phosphoinositide 3-kinase; PIP2: phosphatidylinosital biphosphate 2; PIP3: phosphatidylinosital biphosphate 3; PTEN: phosphatase and tensin homolog; MEK: methyl ethyl ketone; ERK: extracellular signal-regulated kinase ; AKT: protein kinase B; mTOR: mammalian target of rapamycin; MAPK: mitogen-activated protein kinase 
Table 1a: SSAs approved for NETs treatment

\begin{tabular}{|c|c|c|c|c|}
\hline Author/trials & Regimen & Patients enrolled & Results & $\begin{array}{c}\text { Adverse reactions } \\
\quad(\text { grade }>3)\end{array}$ \\
\hline $\begin{array}{l}\text { Rinke } \text { et } a l .{ }^{[49]} \text { Arnold } \text { et } a l .{ }^{[28]} \\
\text { PROMID (Phase III) }\end{array}$ & Octreotide $v s$. placebo & $\begin{array}{l}\text { Advanced GEP or NETs } \\
\text { of unknown origin }\end{array}$ & $\begin{array}{c}\text { mTTP: } 14.3 v s .6 \\
\text { months; SD: } 64 \% v s . \\
37.2 \%\end{array}$ & Diarrhea \\
\hline $\begin{array}{l}\text { Caplin et al. }{ }^{[50]} \text { Clarinet (Phase } \\
\text { III) }\end{array}$ & Lanreotide $v s$. placebo & $\begin{array}{l}\text { Advanced GEP or NETs } \\
\text { of unknown origin }\end{array}$ & $\begin{array}{l}\text { mPFS: NR vs. } 18 \\
\text { months }\end{array}$ & Diarrhea \\
\hline Filosso et al..$^{[57]}$ & Octreotide & $\begin{array}{l}\text { Metastatic atypical } \\
\text { bronchial carcinoid with } \\
\text { carcinoid syndrome } \\
\text { (diarrhea) }\end{array}$ & $\mathrm{RR}=60 \%$ & None \\
\hline
\end{tabular}

GEP: gastro-entero-pancreatic; NETs: neuroendocrine tumors; mTTP: median time to progression; mPFS: median progression free survival; SD: stable disease; NR: not reached; RR: response rate

Table 1b: SSAs not yet approved for NETs treatment

\begin{tabular}{lcccc}
\hline Author/trials & Regimen & Patients enrolled & Results & $\begin{array}{c}\text { Adverse reactions } \\
\text { (grade }>\text { 3) }\end{array}$ \\
\hline Wolin et $a l .{ }^{[53]}$ (Phase III) Pasireotide $v s$. octreotide & Advanced GEP- NETs & mPFS: $11.8 v s .6 .8$ & Hyperglycemia, diarrhea \\
& & & months; SD: $60.8 \%$ vs. & \\
& & & $42.3 \%$ & \\
\hline
\end{tabular}

SSAs: short synthetic analogues of somatostatin; NETs: neuroendocrine tumors; GEP-NETs: gastro-entero-pancreatic neuroendocrine tumors; mPFS: median progression free survival; SD: stable disease

Table 1c: Drug not yet approved for the treatment of refractory carcinoid syndrome

\begin{tabular}{lcccc}
\hline Author/trials & Regimen & Patients enrolled & Results & Adverse reactions (grade $>$ 3) \\
\hline Kulke et al.${ }^{[54]}$ & Telotristat & Metastatic GEP-NETs with & Reduction of BMs: $30 \%$ & Gastrointestinal symptoms: nausea, \\
& & carcinoid syndrome & & vomiting, or abdominal discomfort \\
Pavel et al. ${ }^{[55]}$ & Telotristat & Metastatic well-differentiated & Reduction of BMs: & Gastrointestinal symptoms: nausea, \\
& & NETs with carcinoid syndrome & vomiting, or abdominal discomfort \\
& & (diarrhea) & $43.5 \%$ & \\
\hline
\end{tabular}

GEP-NETs: gastro-entero-pancreatic neuroendocrine tumors; mTTP: median time to progression; mPFS: median progression free survival; BMs: bowel movements; RR: response rate

glucagonomas, and VIPomas (80-100\%). ${ }^{[27,28]}$ However, insulinomas express SSTR in $50-70 \%$ of cases, showing a prevalence of SSTR 5 mRNA expression that is positively correlated with aggressive pathological characteristics. ${ }^{[29]}$

SSTR2 is usually expressed in NENs, and its loss could be highly correlated with the dysregulation of tumor proliferation, consequently promoting tumor growth. ${ }^{[30,31]}$

SSTR1 and SSTR5 are less expressed in NENs and correlate with a major risk of angioinvasion and distant metastasis. SSTR3 is even less present, and SSTR4 is almost absent. ${ }^{[32-34]}$

Reductions of receptor density, changes in their subtype pattern, and probably also their downregulation seem to be a consequence of tumor dedifferentiation. Thus, the presence of SSTRs might also be useful as a specific predictor of prognosis. ${ }^{[16]}$ However, any significant association between the expressed receptors subtypes and the primary tumor site at onset is observed in relation to high and heterogeneous expression of SSTRs, or to a specific hormone secretion. ${ }^{[35-37]}$
SSTR functioning appears different and dependent on the presence in several types of cancer cell, various distributions on cellular surface, and intrinsic features (ability of desensitization, internalization, and cross talk). ${ }^{[2,38]}$ However, their activity causes a blockage of cellular survival, proliferation, differentiation, and hormone secretion, except for SSTR4, promoting cell mitosis through overregulation of Mitogen-activated protein kinase/extracellular signal-regulated kinase $1 / 2$ (MAPK/ERK1/2) pathway.

In fact SSTR1 acts on starting MAPK pathway; SSTR2 augments Src homology region 2 domain-containing phosphatase- 1 and epidermal growth factor receptor (EGFR) activity, over-regulates $\mathrm{p} 21$ and $\mathrm{Rb}$, reducing MAPK activity and blocking cellular proliferation. p53 and Bax, involved in apoptosis, are induced by SSTR3. It also blocks vascular endothelial growth factor receptor (VEGFR). Finally, protein tyrosine phosphatases are targeted by SSTR5. ${ }^{[18,39]}$

The role of SSAs, as mentioned, is to reduce active symptoms and to have an antiproliferative effect in secreting and nonsecreting neuroendocrine tumors. 
Table 2: Principal studies with inhibitors of mTOR

\begin{tabular}{|c|c|c|c|c|}
\hline Author/trials & Regimen & Patients enrolled & Results & $\begin{array}{c}\text { Adverse reactions } \\
(\text { grade }>3)\end{array}$ \\
\hline $\begin{array}{l}\text { Yao et al }{ }^{[64]} \text { RADIANT-1 } \\
\text { (Phase II) }\end{array}$ & $\begin{array}{l}\text { Stratum 1: everolimus } \\
\text { Stratum 2: everolimus } \\
\text { plus octreotide LAR }\end{array}$ & $\begin{array}{l}\text { Metastatic P-NETs after } \\
\text { progression }\end{array}$ & $\begin{array}{c}\text { Stratum 1: mPFS: } 9.7 \\
\text { months } \\
\text { Stratum 2: mPFS: } \\
16.7 \text { months }\end{array}$ & Stomatitis, diarrhea \\
\hline $\begin{array}{l}\text { Pavel et al. }{ }^{[66]} \text { RADIANT-2 } \\
\text { (Phase III) }\end{array}$ & $\begin{array}{c}\text { Everolimus plus } \\
\text { octreotide LAR vs. } \\
\text { placebo plus octreotide } \\
\text { LAR }\end{array}$ & $\begin{array}{l}\text { Advanced NETs with carcinoid } \\
\text { syndrome after progression }\end{array}$ & $\begin{array}{l}\text { mPFS: } 16.4 \text { vs. } 11.3 \\
\text { months }\end{array}$ & $\begin{array}{l}\text { Stomatitis, diarrhea, } \\
\text { fatigue }\end{array}$ \\
\hline $\begin{array}{l}\text { Fazio et al. }{ }^{[67]} \\
\text { RADIANT-2 (Phase III)- } \\
\text { exploratory analysis }\end{array}$ & $\begin{array}{c}\text { Everolimus plus } \\
\text { octreotide LAR vs. } \\
\text { placebo plus octreotide } \\
\text { LAR }\end{array}$ & $\begin{array}{l}\text { Low- to intermediate-grade } \\
\text { advanced lung NETs }\end{array}$ & $\begin{array}{l}\text { mPFS: } 13.6 \text { vs. } 5.6 \\
\text { months }\end{array}$ & $\begin{array}{l}\text { Stomatitis, rash, } \\
\text { diarrhea, fatigue }\end{array}$ \\
\hline $\begin{array}{l}\text { Yao et al }{ }^{[65]} \text { RADIANT-3 } \\
\text { (Phase III) }\end{array}$ & Everolimus vs. placebo & $\begin{array}{l}\text { Advanced P-NETs after } \\
\text { progression }\end{array}$ & $\begin{array}{l}\text { mPFS: } 11.0 \text { vs. } 4.6 \\
\text { months }\end{array}$ & $\begin{array}{l}\text { Stomatitis, diarrhea, } \\
\text { fatigue, nausea, rash }\end{array}$ \\
\hline
\end{tabular}

mTOR : mammalian target of rapamycin; P-NETs: primitive neuroendocrine tumors; mPFS: median progression free survival; LAR: long-acting release

Table 3: Anti-IGF-R1 drugs in NETs

\begin{tabular}{|c|c|c|c|c|}
\hline Author/trials & Regimen & Patients enrolled & Results & $\begin{array}{c}\text { Adverse reactions } \\
(\text { grade }>3)\end{array}$ \\
\hline $\begin{array}{l}\text { Naing et al. }{ }^{[99]} \\
\text { (Phase I) }\end{array}$ & $\begin{array}{l}\text { Cixutumumab plus } \\
\text { temsirolimus }\end{array}$ & $\begin{array}{l}\text { Advanced solid tumors pre- } \\
\text { treated (neuroendocrine tumors) }\end{array}$ & $\mathrm{SD}=47 \%$ & $\begin{array}{c}\text { Hyperglycemia, } \\
\text { hypertriglyceridemia, } \\
\text { hypercholesterolemia, } \\
\text { thrombocytopenia, } \\
\text { mucositis }\end{array}$ \\
\hline $\begin{array}{l}\text { Rothenberg et al. }{ }^{[100]} \\
\text { (Phase I) }\end{array}$ & Ganitumumab & $\begin{array}{l}\text { Advanced solid tumors pre- } \\
\text { treated (neuroendocrine tumors) }\end{array}$ & $\begin{array}{l}\mathrm{PR}=20 \% \\
\mathrm{SD}=80 \%\end{array}$ & Diarrhea \\
\hline $\begin{array}{l}\text { Strosberg et al. } .^{[101]} \\
\text { (Phase II) }\end{array}$ & Ganitumumab & $\begin{array}{l}\text { Metastatic progressive } \\
\text { carcinoid or P-NETs }\end{array}$ & $\begin{array}{c}\text { No objective responders } \\
\text { by RECIST. mPFS }=6.3 \\
\text { months: } 10.5 \text { months for } \\
\text { carcinoid patients, and } 4.2 \\
\text { months for P-NET patients. } \\
\text { OS rate at } 12 \text { months }= \\
66 \%: \mathrm{mOS}=\mathrm{NR}\end{array}$ & $\begin{array}{l}\text { Hyperglycemia, } \\
\text { neutropenia, } \\
\text { thrombocytopenia, } \\
\text { infusion reaction }\end{array}$ \\
\hline
\end{tabular}

IGF: insulinlike growth factor; NETs: neuroendocrine tumors; SD: stable disease; PR: partial response; P-NETs: primitive neuroendocrine tumors; RECIST: response evaluation criteria in solid tumors; mPFS: median progression free survival; OS: overall survival; mOS: median overall survival; NR: not reached

If presented on tumor cells' surface, the blockage of SSTRs operates directly on cell proliferation, stimulating antimitotic and apoptotic activities. SSAs also induce cell growth inhibition with indirect activities (not requiring SSTR neoplasm expression), ${ }^{[40-44]}$ such as angiogenesis inhibition and immunomodulation mechanism, mediated by stimulation of the production of natural-killer cells and blockage of growth factors. ${ }^{[45-48]}$

The results of two international studies (PROMID, using octreotide, and CLARINET trial, using lanreotide) represent the principal reason for using SSAs as firstline medical and systemic therapy in GEP tumors or neuroendocrine tumors of unknown origin, especially for data about progression-free survival (PFS). ${ }^{[49,50]}$ As shown by Rinke et al. ${ }^{[49]}$ in the PROMID study, advanced midgut NENs gained an advantage in time to progression, response rate, and risk reduction of tumor progression from use of octreotide long-acting release (LAR) compared to placebo. Furthermore, octreotide LAR also extends overall survival (OS), but only in the subgroup of patients with metastatic midgut NETs and a low hepatic load $(\leq 10 \% \text { at study entry })^{[51]}$. [Table 1a]

Recently, the CLARINET trial enrolled nonfunctioning GEP-NENs randomized to receive depot lanreotide or placebo and demonstrated an improvement in PFS for patients in the treatment arm [Table 1a]. Due these significant data, octreotide LAR and depot lanreotide have been approved as treatment for patients with newly 
Table 4: Anti-angiogenic drugs in NETs

\begin{tabular}{|c|c|c|c|c|}
\hline Author/trials & Regimen & Patients enrolled & Results & $\begin{array}{c}\text { Adverse reactions } \\
(\text { grade }>3)\end{array}$ \\
\hline $\begin{array}{l}\text { Faivre et al. } .^{[115]} \\
\text { (Phase I) }\end{array}$ & Sunitinib & $\begin{array}{c}\text { Metastatic solid } \\
\text { tumors pre-treated: } \\
\text { (neuroendocrine tumors) }\end{array}$ & $\mathrm{ORR}=20 \%$ & Fatigue, hypertension \\
\hline $\begin{array}{l}\text { Kulke et al. } .^{[116]} \\
\text { (Phase II) }\end{array}$ & Sunitinib & $\begin{array}{l}\text { Carcinoid or pancreatic } \\
\text { neuroendocrine tumor not } \\
\text { candidates for curative } \\
\text { surgery }\end{array}$ & $\begin{array}{c}\mathrm{SD}=82.9 \% \text { in } \\
\text { carcinoid patients. } \\
\mathrm{SD}=68.2 \% \text { in P-NETs } \\
\text { mTTP in carcinoid } \\
\text { tumors }=10.2 \text { months } \\
\text { mTTP in P-NETs }=7.7 \\
\text { months } \\
\text { OS rate at } 12 \text { months } \\
\text { in carcinoid patients: } \\
83.4 \% \text { OS rate at } \\
12 \text { months } 81.1 \% \text { in } \\
\text { P-NETs }\end{array}$ & $\begin{array}{l}\text { Fatigue, hypertension, GI } \\
\text { hemorrhage, pulmonary } \\
\text { embolism, increased lipase, } \\
\text { cardiac congestive failure, } \\
\text { cerebrovascular accident, } \\
\text { hyponatremia }\end{array}$ \\
\hline $\begin{array}{l}\text { Raymond et al. } .^{[17]} \\
\text { (Phase III) }\end{array}$ & Sunitinib vs. placebo & $\begin{array}{l}\text { Low- and intermediate- } \\
\text { grade advanced P-NETs }\end{array}$ & $\begin{aligned} \text { mPFS } & =11.4 \text { vs. } 5.5 \\
\text { months } & \\
\text { ORR } & =9.3 \% \text { vs. } 0 \\
\text { OS rate } & =25 \% \text { vs. } 10 \%\end{aligned}$ & $\begin{array}{l}\text { Diarrhea, nausea, vomiting, } \\
\text { fatigue }\end{array}$ \\
\hline $\begin{array}{l}\text { Yao et al. }{ }^{[118]} \text { (Phase } \\
\text { II) }\end{array}$ & $\begin{array}{l}\text { Octreotide plus } \\
\text { bevacizumab } v s \text {. } \\
\text { octreotide plus } \\
\text { pegylated IFN } \alpha 2 \mathrm{~b}\end{array}$ & $\begin{array}{l}\text { Metastatic or unresectable } \\
\text { carcinoid tumors }\end{array}$ & $\begin{array}{c}\mathrm{SD}=77 \% \text { vs. } 68 \% \\
\text { PFS rate: } 95 \% \text { vs. } 68 \%\end{array}$ & $\begin{array}{c}\text { Granulocytopenia, headache, } \\
\text { hypertension }\end{array}$ \\
\hline $\begin{array}{l}\text { Chan et al. } .^{[120]} \\
\text { (Phase II) }\end{array}$ & $\begin{array}{l}\text { Bevacizumab plus } \\
\text { temozolomide }\end{array}$ & $\begin{array}{l}\text { Locally advanced or } \\
\text { metastatic NETs }\end{array}$ & $\begin{array}{l}\text { ORR }=15 \%(33 \% \text { in } \\
\text { P-NETs and } 0 \% \text { in } \\
\text { carcinoid tumors }) \\
\text { mPFS }=11.0 \text { months } \\
\quad(14.3 \text { for P-NETs } \\
\text { vs. } 7.3 \text { months for } \\
\text { carcinoid tumors). mOS } \\
=33.3 \text { months }(41.7 \text { for } \\
\text { P-NETs } v s .18 .8 \text { months } \\
\text { for carcinoid tumors })\end{array}$ & Lymphopenia, thrombocytopenia \\
\hline $\begin{array}{l}\text { YAO et al. } .^{[121]} \\
\text { (Phase II) }\end{array}$ & $\begin{array}{l}\text { Everolimus alone } \\
\text { with the combination } \\
\text { of everolimus and } \\
\text { bevacizumab }\end{array}$ & Advanced P-NETs & $\mathrm{ORR}=26 \%$ & - \\
\hline \multirow[t]{2}{*}{$\begin{array}{l}\text { Ahn et al. }{ }^{[123]} \text { (Phase } \\
\text { II) }\end{array}$} & Pazopanib & $\begin{array}{c}\text { Advanced GEP NENs, not } \\
\text { amenable to loco-regional } \\
\text { therapies }\end{array}$ & $\begin{array}{c}\mathrm{ORR}=18.9 \% \\
\mathrm{SD}=56.8 \% \\
\mathrm{DCR}=75.7 \%\end{array}$ & $\begin{array}{c}\text { Proteinuria, neutropaenia, } \\
\text { hypertension, diarrhea, anorexia, } \\
\text { abdominal pain, AST/ALT } \\
\text { elevation }\end{array}$ \\
\hline & $\begin{array}{l}\text { Pazopanib plus } \\
\text { octreotide }\end{array}$ & $\begin{array}{c}\text { Metastatic or locally } \\
\text { advanced grade } 1-2 \\
\text { carcinoid tumours or } \\
\text { P-NETs }\end{array}$ & $\begin{array}{c}\text { ORR }=21.9 \% \text { of } \\
\text { P-NETs } \\
\text { ORR }=0 \% \text { in GI-NETs } \\
\text { PFS: } 14.2 \text { months in } \\
\text { P-NETs, } \\
\text { PFS }=12 \text { months in } \\
\text { GI-NETs }\end{array}$ & $\begin{array}{l}\text { Hypertriglyceridemia, } \\
\text { thrombosis. }\end{array}$ \\
\hline
\end{tabular}

ORR: overall response rate; SD: stable disease; P-NETs: primitive neuroendocrine tumors; GI: gastrointestinal; OS: overall survival; mPFS: median progression free survival; mOS: median overall survival; GEP NENs: Gastro-entero-pancreatic neuroendocrine neoplasms; DCR: disease control rate; IFN: Interferon; AST/ALT: aspartate transaminase/alanine transaminase; GI-NETs: gastrointestinal neuroendocrine tumors; PFS: progression free survival

diagnosed, recurrent, and advanced neuroendocrine primary tumor, hormone-secreting status, and presence tumors in progressive disease, irrespective of site of of symptoms. 
Pasireotide, a new somatostatin analogue, may represent an effective therapeutic option in tumors that are refractory to octreotide or lanreotide. ${ }^{[52]}$ In a phase III randomized, blinded study, pasireotide showed symptom control comparable to octreotide but with an improved $\operatorname{PFS}(P=0.045) .^{[53]}$ [Table 1b]

Another drug, telotristat etiprate, inhibitor of serotonin synthesis, was studied in patients with carcinoid syndrome characterized by diarrhea. Kulke et al. ${ }^{[54]}$ and Pavel et al. ${ }^{[55]}$ conducted a prospective single-arm study in patients with functional tumor and diarrhea $(\geq 4$ bowel movements/day) not well controlled by octreotide. Telotristat etiprate was shown to reduce both the frequency of bowel movements and biochemical markers of carcinoid syndrome [Table 1c].

In contrast, there are no validated prospective clinical trials that guide the treatment of advanced bronchopulmonary carcinoids. Small retrospective mono-institutional data and subgroup analysis of some multicentric trials involving gastro-entero-pancreatic NETs represent the only available results. In particular SSAs seem to produce tumor stabilization in about 30$70 \%$ of patients with low-grade BP-NETs. ${ }^{[56]}$

Filosso et al. ${ }^{[57]}$ demonstrated that octreotide is effective in reducing symptoms of carcinoid syndrome and urinary 5-hydroxyindoleacetic acid values in patients with liver metastases of radically resected atypical bronchial carcinoid. The efficacy of the drug seemed to be related to the expression of SST2 somatostatin receptors in the pathologic tissue, as demonstrated by polymerase chain reaction method [Table 1a]. In the setting of thoracic NETs, the first multicentric randomized prospective trial investigating either pasireotide in combination with Mammalian target of rapamycin (mTOR) inhibitor or pasireotide alone is still ongoing.

\section{mTOR INHIBITORS}

Everolimus, mTOR inhibitor, represents another important option for NETs treatment. In fact, mTOR has been identified as a kinase activated in the Ras/Raf, MAPK, Phosphoinositide 3-Kinase (PI3K)-Protein Kinase B (AKT) pathway of GEP and BP-NETs. ${ }^{[58]}$ [Figure 1]

Recently, overexpression of mTOR and/or its pathway targets has been shown to be very common in GEPNETs, resulting in higher proliferative activity and adverse clinical outcomes. ${ }^{[59,60]}$ Furthermore, somatic mutations of PI3K are individuated in a minority of P-NETs and are described also in bronchopulmonary carcinoids. PI3K/AKT/mTOR pathway, then, is especially switched on among P-NETs promoting the principal cellular functions. ${ }^{[61-63]}$ Currently, a phase Ib trial with everolimus in association with PI3K inhibitor is ongoing (ClinicalTrials. Gov Identifier: NCT02077933).
Tumorigenesis and metastatic power in NENs seem to be conditioned by a great number of intracellular pathways, as transduction mechanisms involving receptor tyrosine kinases and G-protein coupled receptors. mTOR and Jun N-terminal kinase seem to modulate their action by contributing to increased cell growth and number.

Everolimus plus octreotide demonstrated a benefit in PFS for GEP-NETs patients with progressive disease. These data emerged from the phase II RAD001 in advanced neuroendocrine tumors trial (RADIANT-1). ${ }^{[64]}$ [Table 2]

Everolimus is currently approved for the treatment of P-NETs in progressive disease, with or without concomitant SSAs therapies, on the basis of the results achieved from RADIANT-3 trial. ${ }^{[65]}$ [Table 2]

A large prospective phase III multicentric study (RADIANT-4) investigating the efficacy of everolimus $v s$. placebo in progressive GI and BP-NETs has recently been completed. Everolimus has received approval for this indication in early 2016.

The mTOR inhibitors have rapidly become of clinical interest in thoracic NETs. Everolimus (alone or in combination with SSAs) was effective, according to exploratory analysis of low- to intermediate-grade advanced lung NETs in the large multicentric phase 3, randomized, placebo-controlled RADIANT II study. These clinically significant data reinforce the necessity of further research of everolimus treatment regimens in this patient setting. ${ }^{[66,67]}$ [Table 2]

For this reason, the LUNA trial, exclusively enrolling patients with thoracic NETs after disease progression, has been performed and awaits definite data consolidation. It has examined the efficacy of everolimus in monotherapy, everolimus in association with pasireotide, or pasireotide alone. (ClinicalTrials. Gov Identifier: NCT01563354)

Another mTOR inhibitor, temsirolimus, was investigated in NETs without any report of success. ${ }^{[68]}$ However, a resistance to $\mathrm{mTOR}$ inhibition and a greater propensity toward further metastasis was observed and seems to be related to the loss of another fundamental target, phosphatase and tensin homologue (PTEN).$^{[69-73]}$ PTEN is localized in the cytosol and in the nucleus, blocking PI3K activity in the cytosol and securing the genome in the nucleus. Its starting through internalization correlates with to a reduction of AKT. ${ }^{[74-76]}$ PTEN is frequently mutated in P-NETs and its low expression correlates with high grading. ${ }^{[77]}$ In particular, low expression in cytosol of lung NETs indicates a category of patient with poor prognosis. ${ }^{[78]}$

\section{IGF1 INHIBITORS}

Insulin growth factor 1 (IGF1), a factor involved in tumor progression, is secreted by neuroendocrine 
neoplasms. ${ }^{[79-80]}$ IGF-1 receptors (IGF-1R), binding IGF-1, activate signals inside normal neuroendocrine cell, through components of the PI3K/Akt/mTOR and the Ras/Raf/MEK/ERK pathways, ${ }^{[82-86]}$ inducing cellular proliferation and over-regulating antiapoptotic activity. ${ }^{[81]}$ [Figure 1] IGF-1 receptors, then, are usually overexpressed in NETs, ${ }^{[87-90]}$ especially in symptomatic and functioning ones. This represents a possible role in tumorigenesis of GEP and bronchial NETs and a potential target for therapy. ${ }^{[91-93]}$ The rationale for the use of IGF1R inhibitors depends on their theoretical capability to reduce AKT phosphorylation induced by mTOR inhibitors. ${ }^{[94-96]}$

In this regard, cixutumumab, a fully human immunoglobulin G1 monoclonal antibody competitively binding IGF-1R, is in the early phases of clinical progress. ${ }^{[97]}$ Cixutumumab is still studied in association with octreotide LAR in an ongoing phase II study enrolling patients with progressing metastatic P-NETs and midgut carcinoid tumors. ${ }^{[98]}$ Also, the combination of cixutumumab, everolimus, and octreotide is being evaluated in a phase I trial conducted in patients with advanced low- or intermediate-grade neuroendocrine tumors for which standard curative measures do not exist (Clinical Trial: NCT01204476). Another similar phase I trial was performed in advanced cancer patients, with candidates receiving temsirolimus with cixutumumab. The preliminary results showed good tolerance. ${ }^{[99]}$ [Table 3]

Similarly, ganitumumab, another fully human monoclonal antibody against IGF-1R, is undergoing evaluation in clinical trials. Rothenberg et al. ${ }^{[100]}$ demonstrated encouraging activity and good tolerance in a phase I trial including previously treated metastatic NET patients [Table 3]. Strosberg et al. ${ }^{[101]}$ performed a phase II study of ganitumumab in patients with metastatic progressive low- and intermediate-grade carcinoids or P-NETs. This trial showed a good tolerance of ganitumumab, but no objective responders [Table 3]. Further studies are necessary to deepen the role of cixutumumab and ganitumumab and to identify other IGF-1R targets.

\section{VEGF AND ITS RECEPTOR INHIBITORS}

Neuroendocrine neoplasms, especially for midgut and P-NETs and bronchial carcinoids, are highly vascularized and overexpress vascular endothelial growth factor (VEGF) and its receptors. ${ }^{[102,103]}$ Four VEGF forms are individuated and examined: VEGF-A, VEGF-B, VEGF-C, and VEGF-D, ${ }^{[104-108]}$ with a different affinity to their three own receptors. ${ }^{[109-113]}$ [Figure 1] For these reasons, the interest of angiogenesis inhibition was encouraged.

The small molecule tyrosine kinase inhibitor (TKI) sunitinib has been studied as a targeted therapy option in NENs. Based on these results in term of response rate that were observed in phase I trial with sunitinib, ${ }^{[14,115]}$
Kulke et al. ${ }^{[116]}$ conducted a phase II trial evaluating the efficacy of sunitinib in GEP-NETs. They showed a significant antitumor activity in P-NETs vs. carcinoid tumors and good tolerance. In addition, in a phase III trial involving low- and intermediate-grade advanced P-NETs, Raymond et al.$^{[117]}$ demonstrated a better PFS in the arm of sunitinib compared to placebo. The improved PFS did not depend on previous treatments or concomitant SSAs. Therefore, sunitinib is approved for the treatment of P-NETs after disease progression.

Considering the importance of VEGF in the pathogenesis of NENs, bevacizumab, an anti-VEGF antibody, has been used either alone or in combination with other drugs with favorable results. A phase II trial, in particular, enrolled patients with advanced carcinoid tumors with stable doses of octreotide to receive either bevacizumab or pegylated Interferon $\alpha 2 \mathrm{~b}$. Bevacizumab showed superiority in objective responses, reduction of tumor blood flow, and PFS. ${ }^{[118,119]}$ Bevacizumab in association with temozolomide in patients with metastatic NETs also showed a major response rate, PFS, and OS in P-NETs. ${ }^{[120]}$

In another recently completed phase II study, everolimus and bevacizumab were shown to be associated with an overall tumor response rate of $26 \%$ and good tolerance in advanced P-NETs. ${ }^{[121]}$ Therefore, a further phase II trial will compare everolimus alone with the combination of everolimus and bevacizumab in patients with P-NETs, in order to find supplementary function of antiangiogenetic agents in this setting of patients (ClinicalTrials. Gov Identifier: NCT01229943). Randomized studies of antiVEGF TKI should also be evaluated in patients with advanced carcinoid tumors.

Pazopanib is an oral bioavailable, multitargeted tirosine kinase inhibitor (VEGF receptors 1, 2, and 3), involved in reducing neoplastic growth and dissemination. ${ }^{[122]}$ Ahn et al. ${ }^{[123]}$ demonstrated, in a non-randomized, openlabeled, single-center phase II trial, that pazopanib in monotherapy was as effective as the other available targeted therapies, not only in P-NETs, but also in GI NETs [Table 4]. Phan et al. ${ }^{[124,125]}$ found that pazopanib in combination with octreotide LAR depot was more effective in advanced G1-G2 P-NETs than in advanced carcinoid tumors [Table 4].

Other trials with pazopanib, and with other multitarget agents such as famitinib (c-kit, platelet-derived growth factor receptor (PDGFR), VEGFR2, VEGFR3, Flt1 and Flt3 inhibitor), regorafenib (c-Raf; BRAF, VEGFR-1,2,3; PDGFR $\alpha$, Fibroblast Growth Factor Receptor (FGFR)1; c-kit; RET; Flt-3 inhibitor), and nintedanib (VEGFR, FGFR, PDGFR inhibitor) are ongoing. Some of them are also enrolling patients with bronchopulmonary NETs (Clinical Trial: NCT01280201; NCT01994213; NCT02259725; NCT02399215). ${ }^{[126-128]}$ 


\section{EGF AND ITS RECEPTOR AND TGF $\alpha$}

EGFR/AKT/mTOR pathway activation could be shown in all entities of NETs and was observed especially in tumors with high grading and poor prognosis. Typical and atypical bronchopulmonary carcinoids ${ }^{[129]}$ and gastrointestinal-neuroendocrine tumours (GI-NETs) and P-NETs present and over-regulate EGFRs. ${ }^{[130]}$ [Figure 1] Papouchado et al.$^{[131]}$ in particular, described a higher presence of EGFR (>91\%) in GI-NETs, especially rectal NETs, than in P-NETs $(<25 \%)$.

An elevated presence of EGFR and transforming growth factor alpha (TGF $\alpha)$ in P-NETs was observed by Srivastava et al. ${ }^{[132]}$ An elevated amount of secreted TGF $\alpha$ was detected in cultures of carcinoid tumors and pheochromocytomas, and the administration octreotide and anti-EGFR monoclonal antibodies seemed to reduce the secretion and the proliferative effect of TGF $\alpha .{ }^{[133]}$ Krishnamurthy et al. ${ }^{[134]}$ showed a high expression of TGF $\alpha$ in GI NETs (72\%) without any correlation with tumor size, grading, and other pathologic features, but only depending on the technique used (immunohistochemistry or northern blot analysis). ${ }^{[133]}$ In rectal NENs TGF- $\alpha$ expression seemed to be increased in lesions larger than $5 \mathrm{~mm}$ and tumors with higher Ki67 index. ${ }^{[135]}$ Despite the heterogeneity of these results, EGFR and its signal transduction pathways (RAS-RAFMAPK) might represent an interesting target for the treatment of NETs.

In fact, a synergistic effect in determining apoptosis in atypical carcinoid cell lines was demonstrated by the association of epidermal growth factor (EGF) receptor inhibitors (erlotinib) with everolimus in in-vitro studies. ${ }^{[129]}$

A phase II trial evaluated gefitinib in 96 pretreated patients affected by GEP-NETs achieved prolonged disease control with rare objective responses; the study drug was well-tolerated. ${ }^{[136]}$

\section{OTHER TYROSINE KINASE INHIBITORS AND IMMUNOTHERAPY}

Beta fibroblast growth factor (bFGF) and c-kit/Platelet Derived Growth Factor (PDGF) inhibitors are being developed, based upon the variable expression of bFGF, c-kit and PDGF in NETs. ${ }^{[137-139]}$

Despite little systematic and rigorous in-depth analysis of immunotherapy in NETs (interferon and dendritic cell vaccines), the recent progress in targeting of Cytotoxic T lymphocyte antigen-4 and PD-1 provide opportunities for future advances. ${ }^{[140]}$ Further studies are necessary to examine the variable expression of PD-1, PD-L1/L2 in NENs.

\section{CONCLUSION}

The predictive and prognostic characteristics of NETs are still under investigation to individuate a pattern of peculiar molecular genetic alterations in each kind of neoplasm. The aim is to find a correlation of specific abnormalities implicated in carcinogenesis and dissemination that may provide potential targets for tailored biotherapy.

In GEP and lung NETs, carcinogenesis and dissemination often involves SSTRs, mTOR/Akt/PI3K and PTEN, IGF-1, VEGF, EGF, TGF, FGF and c-kit/PDGF and its corresponding receptors, markers whose established value may more thoroughly define an appropriate course of treatment.

\section{Financial support and sponsorship Nil.}

\section{Conflicts of interest}

There are no conflicts of interest.

\section{Patient consent}

No patient involved.

\section{Ethics approval}

This article does not contain any studies with human participants or animals.

\section{REFERENCES}

1. Cives M, Strosberg J. An update on gastroenteropancreatic neuroendocrine tumours. Oncology (Williston Park) 2014;28:749-56, 758.

2. Rindi G, Arnold R, Bosman FT, Capella C, Klimstra DS, Kloppe G, Komminoth P, Solcia E. Nomenclature and classification of neuroendocrine neoplasms of the digestive system. In WHO Classification of Tumours of the Digestive System, Eds. FT Bosman, F Carneiro, RH Hruban \& N Theise. Lyon: IARC Press. 2010. p. 13-14.

3. Sorbye H, Strosberg J, Baudin E, Klimstra DS, Yao JC Gastroenteropancreatic high-grade neuroendocrine carcinoma. Cancer 2014;120:2814-23.

4. La Rosa S, Sessa F. High-grade poorly differentiated neuroendocrine carcinomas of the gastroenteropancreatic system: from morphology to proliferation and back. Endocr Pathol 2014;25:193-8.

5. Capdevila J, Salazar R, Halperin I, Abad A, Yao JC. Innovations therapy: mammalian target of rapamycin (mTOR) inhibitors for the treatment of neuroendocrine tumours. Cancer Metastasis Rev 2011;30:27-34.

6. Capdevila J, Tabernero J. A shining light in the darkness for the treatment of pancreatic neuroendocrine tumours. Cancer Discov 2011;1:213-21.

7. Hilfenhaus G, Gohrig A, Pape UF, Neumann T, Jann H, Zdunek D, Hess G, Stassen JM, Wiedenmann B, Detjen K, Pavel M, Fischer C. Placental growth factor supports neuroendocrine tumour growth and predicts disease prognosis in patients. Endocr Relat Cancer 2013;20:305-19.

8. Vallières E, Shepherd FA, Crowley J, Van Houtte P, Postmus PE, Carney D, Chansky K, Shaikh Z, Goldstraw P; International Association for the Study of Lung Cancer International Staging Committee and Participating Institutions. The IASLC Lung Cancer 
Staging Project: proposals regarding the relevance of TNM in the pathologic staging of small cell lung cancer in the forthcoming (seventh) edition of the TNM classification for lung cancer. $J$ Thorac Oncol 2009;4:1049-59.

9. Faggiano A, Sabourin JC, Ducreux M, Lumbroso J, Duvillard P, Leboulleux S, Dromain C, Colao A, Schlumberger M, Baudin E. Pulmonary and extrapulmonary poorly differentiated large cell neuroendocrine carcinomas: diagnostic and prognostic features. Cancer 2007;110:265-74.

10. Travis WD. Advances in neuroendocrine lung tumors. Ann Oncol 2010; 21 Suppl 7:vii65-71.

11. Rekhtmann N. Neuroendocrine tumors of the lung: an update. Arch Pathol Lab Med 2010;134:1628-38.

12. Bertino EM, Confer PD, Colonna JE, Ross P, Otterson GA. Pulmonary neuroendocrine/carcinoid tumors. Cancer 2009;115:4434-41.

13. Valente M, Catena L, Milione M, Pusceddu S, Formisano B, Bajetta E. Common diagnostic challenges in the histopathologic diagnosis of neuroendocrine lung tumors: a case report. Case Rep Oncol 2010;3:202-7.

14. Oberg KE. The management of neuroendocrine tumours: current and future medical therapy options. Clin Oncol (R Coll Radiol) 2012;24:282-93.

15. Reubi JC. Peptide receptors as molecular targets for cancer diagnosis and therapy. Endocr Rev 2003;24:389-427.

16. Modlin IM, Pavel M, Kidd M, Gustafsson BI. Review article: somatostatin analogues in the treatment of gastroenteropancreatic neuroendocrine (carcinoid) tumours. Aliment Pharmacol Ther 2010;31:169-88.

17. Bruns C, Lewis I, Briner U, Meno-Tetang G, Weckbecker G. SOM230: a novel somatostatin peptidomimetic with broad somatotropin release inhibiting factor (SRIF) receptor binding and a unique antisecretory profile. Eur J Endocrinol 2002;146:707-16.

18. Patel YC. Somatostatin and its receptor family. Front Neuroendocrinol 1999;20:157-98.

19. Møller LN, Stidsen CE, Hartmann B, Holst JJ. Somatostatin receptors. Biochim Biophys Acta 2003;1616:1-84.

20. Ruszniewski P, Ducreux M, Charyvialle JA, Blumberg J, Cloarec D, Michel H, Raymond JM, Dupas JL, Gouerou H, Jian R, Genestin E, Bernades P, Rougier P. Treatment of the carcinoid syndrome with the long acting somatostatin analogue lanreotide: a prospective study in 39 patients. Gut 1996;39:279-83.

21. Yamada Y, Post SR, Wang K, Tager HS, Bell GI, Seino S. Cloning and functional characterization of a family of human and mouse somatostatin receptors expressed in brain, gastrointestinal tract, and kidney. Proc Natl Acad Sci U S A 1992;89:251-5.

22. Yamada Y, Reisine T, Law SF, Ihara Y, Kubota A, Kagimoto S, Seino M, Seino Y, Bell GI, Seino S. Somatostatin receptors, an expanding gene family: cloning and functional characterization of human SSTR3, a protein coupled to adenylate cyclase. Mol Endocrinol 1992;6:2136-42.

23. Ben-Shlomo A, Zhou C, Pichurin O, Chesnokova V, Liu NA, Culler MD, Melmed S. Constitutive somatostatin receptor activity determines tonic pituitary cell response. Mol Endocrinol 2009;23:337-48.

24. Cescato R, Loesch KA, Waser B, Mäcke HR, Rivier JE, Reubi JC, Schonbrunn A. Agonist-biased signalling at the sst2A receptor: the multi-somatostatin analogs KE108 and SOM230 activate and antagonize distinct signalling pathways. Mol Endocrinol 2010;24:240-9.

25. Reubi JC, Eisenwiener KP, Rink H, Waser B, Mäcke HR. A new peptidic somatostatin agonist with high affinity to all five somatostatin receptors. Eur J Pharmacol 2002;456:45-9.

26. Schonbrunn A. Selective agonism in somatostatin receptor signalling and regulation. Mol Cell Endocrinol 2008;286:35-9.

27. Ferone D, Arvigo M, Semino C, Jaquet P, Saveanu A, Taylor JE, Moreau JP, Culler MD, Albertelli M, Minuto F, Barreca A. Somatostatin and dopamine receptor expression in lung carcinoma cells and effects of chimeric somatostatin-dopamine molecules on cell proliferation. Am J Physiol Endocrinol Metab 2005;289:E1044-50.

28. Arnold R, Trautmann ME, Creutzfeldt W, Benning R, Benning M, Neuhaus C, Jürgensen R, Stein K, Schäfer H, Bruns C, Dennler HJ. Somatostatin analogue octreotide and inhibition of tumour growth in metastatic endocrine gastroenteropancreatic tumours. Gut 1996;38:430-8.

29. De Sà SV, Corrêa-Giannella ML, Machado MC, de Souza JJ, Pereira MA, Patzina RA, Siqueira SA, Machado MC, GiannellaNeto D. Somatostatin receptors subtype 5 (SSTR5) mRNA expression is related to histopatological features of cell proliferation in insulinomas. Endocr Relat Cancer 2006;13:69-78.

30. Schmid HA, Lambertini C, van Vugt HH, Barzaghi-Rinaudo P, Schafer J, Hillenbrand R, Sailer AW, Kaufmann M, Nuciforo P. Monoclonal antibodies against the human somatostatin receptor subtypes 1-5: development and immunohistochemical application in neuroendocrine tumours. Neuroendocrinology 2012;95:232-47.

31. Reubi JC, Laissue J, Krenning E, Lamberts SW. Somatostatin receptors in human cancer: incidence, characteristics, functional correlates and clinical implications. J Steroid Biochem Mol Biol 1992;4:27-35.

32. Reubi JC. Peptide receptors as molecular targets for cancer diagnosis and therapy. Endocr Rev 2003;24:389-427.

33. Reubi JC, Waser B. Concomitant expression of several peptide receptors in neuroendocrine tumours: molecular basis for in vivo multireceptor tumour targeting. Eur J Nucl Med Mol Imaging 2003;30:781-93.

34. Reubi JC. Somatostatin and other Peptide receptors as tools for tumour diagnosis and treatment. Neuroendocrinology 2004;80 Suppl 1:51-6.

35. Reubi JC, Kappeler A, Wase B, Laissue J, Hipkin RW, Schonbrunn A. Immunoistochemical localisation of somatostatin receptros SST2A in human tumours. Am J Pathol 1998;153:233-45.

36. Papotti M, Bongiovanni M, Volante M, Allìa E, Landolfi S, Helboe L, Schindler M, Cole SL, Bussolati G. Expression of somatostatin receptros type 1-5 in 81 cases og gastrointestinal and pancreatic endocrine tumours. A correlative immunohistochemical and reverse-transcriptase polymerase chain reaction analysis. Virchovs Arch 2002;440:461-75.

37. Volante M, Rosas R, Allìa E, Granata R, Baragli A, Muccioli G, Papotti M. Somatostatin, cortistatin and their receptors in tumours Mol Cell Endocrinol 2008;286:219-29.

38. Lahlou H, Guillermet J, Hortala M, Vernejoul F, Pyronnet S, Bousquet C, Susini C. Molecular signalling of somatostatin receptors. Ann N Y Acad Sci 2004;1014:121-31.

39. Reisine T, Bell GI. Molecular biology of somatostatin receptors. Endocr Rev 1995;16:427-42.

40. Lamberts SW, Krenning EP, Reubi JC. The role of somatostatin and its analogs in the diagnosis and treatment of tumours. Endocr Rev 1991;12:450-82.

41. Bousquet C, Puente E, Buscail L, Vaysse N, Susini C. Antiproliferative effect of somatostatin and analogs. Chemotherapy 2001;47 Suppl 2:30-9.

42. Butturini G, Bettini R, Missiaglia E, Mantovani W, Dalai I, Capelli P, Ferdeghini M, Pederzoli P, Scarpa A, Falconi M. Predictive factors of efficacy of the somatostatin analogue octreotide as first line therapy for advanced pancreatic endocrine carcinoma. Endocr Relat Cancer 2006;13:1213-21.

43. Schally AV. Oncological applications of somatostatin analogues. Cancer Res 1988;48:6977-85

44. Weckbecker G, Raulf F, Stolz B, Bruns C. Somatostatin analogs for diagnosis and treatment of cancer. Pharmacol Ther 1993;60:245-64

45. Pollak MN, Schally AV. Mechanisms of antineoplastic action of somatostatin analogs. Proc Soc Exp Biol Med 1998;217:143-52.

46. Froidevaux S, Eberle AN. Somatostatin analogs and radiopeptides in cancer therapy. Biopolymers 2002;66:161-83.

47. Schally AV, Nagy A. Chemotherapy targeted to cancers through tumoural hormone receptors. Trends Endocrinol Metab 2004; $15: 300-10$. 
48. Pyronnet S, Bousquet C, Najib S, Azar R, Laklai H, Susini C. Antitumour effects of somatostatin. Mol Cell Endocrinol 2008;286:230-7.

49. Rinke A, Müller HH, Schade-Brittinger C, Klose KJ, Barth P, Wied M, Mayer C, Aminossadati B, Pape UF, Bläker M, Harder J, Arnold C, Gress T, Arnold R; PROMID Study Group. Placebocontrolled, double-blind, prospective, randomized study on the effect of octreotide LAR in the control of tumour growth in patients with metastatic neuroendocrine midgut tumours: a report from the PROMID Study Group. J Clin Oncol 2009;27:4656-63.

50. Caplin ME, Pavel M, Ćwikla JB, Phan AT, Raderer M, Sedláčková E, Cadiot G, Wolin EM, Capdevila J, Wall L, Rindi G, Langley A, Martinez S, Blumberg J, Ruszniewski P; CLARINET Investigators. Lanreotide in metastatic enteropancreatic neuroendocrine tumours. N Engl J Med 2014;371:224-33.

51. Arnold R, Wittenberg M, Rinke A, Schade-Brittinger C, Aminossadati B, Ronicke Gress TM, Mueller HH; PROMID Study Group; Philipps University Marburg, Department of Internal Medicine, Division of Gastroenterology and Endocrinology, Marburg, Germany; KKS Marburg, Marburg, Germany; Philipps University Marburg; Deptartment of Gastroenterology, Marburg, Germany; Koordinierungszentrum für Klinische Studien der Philipps-Universität Marburg, Marburg, Germany; Institute of Medical Informatics, Biometry and Epidemiology, LMU Munich, München, Germany. PROMID Study Group. Placebo controlled, double blind, prospective, randomized study on the effect of octreotide LAR in the control of tumour growth in patients with metastatic neuroendocrine midgut tumours (PROMID): results on long-term survival. ASCO 2013;31:Abstr 4030.

52. Schmid HA. Pasireotide (SOM230): development, mechanism of action and potential applications. Mol Cell Endocrinol 2008;286:69-74.

53. Wolin EM, Jarzab B, Eriksson B, Walter T, Toumpanakis C, Morse MA, Tomassetti P, Weber MM, Fogelman DR, Ramage J, Poon D, Gadbaw B, Li J, Pasieka JL, Mahamat A, Swahn F, Newell-Price J, Mansoor W, Öberg K. A multicenter, randomized, blinded, phase III study of pasireotide LAR versus octreotide LAR in patients with metastatic neuroendocrine tumours (NET) with disease-related symptoms inadequately controlled by somatostatin analogs. $J$ Clin Oncol 2013;31:abstr s4031.

54. Kulke MH, O’Dorisio T, Phan A, Bergsland E, Law L, Banks P, Freiman J, Frazier K, Jackson J, Yao JC, Kvols L, Lapuerta P, Zambrowicz B, Fleming D, Sands A. Telotristat etiprate, a novel serotonin synthesis inhibitor, in patients with carcinoid syndrome and diarrhea not adequately controlled by octreotide. Endocr Relat Cancer 2014;21:705-14.

55. Pavel M, Hörsch D, Caplin M, Ramage J, Seufferlein T, Valle J, Banks P, Lapuerta P, Sands A, Zambrowicz B, Fleming D, Wiedenmann B. Telotristat etiprate for carcinoid syndrome: a singlearm, multicenter trial. J Clin Endocrinol Metab 2015;100:1511-9.

56. Aparicio T, Ducreux M, Baudin E, Sabourin JC, De Baere T, Mitry E, Schlumberger M, Rougier P. Antitumour activity of somatostatin analogues in progressive metastatic neuroendocrine tumours. Eur $J$ Cancer 2001;37:1014-9.

57. Filosso PL, Ruffini E, Oliaro A, Papalia E, Donati G, Rena O. Longterm survival of atypical bronchial carcinoids with liver metastases, treated with octreotide. Eur J Cardiothorac Surg 2002;21:913-7.

58. Hay N. The Akt-mTOR tango and its relevance to cancer. Cancer Cell 2005;8:179-83.

59. Alonso-Gordoa T, Capdevila J, Grande E. GEP-NETs Update: Biotherapy for neuroendocrine tumours. Eur $J$ Endocrinol 2015;172:R31-46.

60. Jiao Y, Shi C, Edil BH, de Wilde RF, Klimstra DS, Maitra A, Schulick RD, Tang LH, Wolfgang CL, Choti MA, Velculescu VE, Diaz LA Jr, Vogelstein B, Kinzler KW, Hruban RH, Papadopoulos N. DAXX/ ATRX, MEN1, and mTOR pathway genes are frequently altered in pancreatic neuroendocrine tumours. Science 2011;331:1199-203.

61. Missiaglia E, Dalai I, Barbi S, Beghelli S, Falconi M, della Peruta M, Piemonti L, Capurso G, Di Florio A, delle Fave G, Pederzoli
P, Croce CM, Scarpa A. Pancreatic endocrine tumours: expression profiling evidences a role for AKT-mTOR pathway. J Clin Oncol 2010;28:245-55.

62. Humar R, Kiefer FN, Berns H, Resink TJ, Battegay EJ. Hypoxia enhances vascular cell proliferation and angiogenesis in vitro via rapamycin (mTOR)-dependent signalling. FASEB J 2002;16:771-80

63. Hanahan D, Weinberg RA. Hallmarks of cancer: the next generation. Cell 2011;144:646-74.

64. Yao JC, Lombard-Bohas C, Baudin E Kvols LK, Rougier P, Ruszniewski P, Hoosen S, St Peter J, Haas T, Lebwohl D, Van Cutsem E, Kulke MH, Hobday TJ, O’Dorisio TM, Shah MH, Cadiot G, Luppi G, Posey JA, Wiedenmann B. Daily oral everolimus activity in patients with metastatic pancreatic neuroendocrine tumours after failure of cytotoxic chemotherapy: a phase II trial. $J$ Clin Oncol 2010;28:69-76.

65. Yao JC, Shah MH, Ito T, Bohas CL, Wolin EM, Van Cutsem E, Hobday TJ, Okusaka T, Capdevila J, de Vries EG, Tomassetti P, Pavel ME, Hoosen S, Haas T, Lincy J, Lebwohl D, Öberg K; RAD001 in Advanced Neuroendocrine Tumors, Third Trial (RADIANT-3) Study Group. Everolimus for advanced pancreatic neuroendocrine tumours. N Engl J Med 2011;364:514-23.

66. Pavel ME, Hainsworth JD, Baudin E, Peeters M, Hörsch D, Winkler RE, Klimovsky J, Lebwohl D, Jehl V, Wolin EM, Oberg K, Van Cutsem E, Yao JC; RADIANT-2 Study Group. Everolimus plus octreotide long-acting repeatable for the treatment of advanced neuroendocrine tumours associated with carcinoid syndrome (RADIANT- 2): a randomised, placebo-controlled, phase 3 study. Lancet 2011;378:2005-12.

67. Fazio N, Granberg D, Grossman A, Saletan S, Klimovsky J, Panneerselvam A, Wolin EM. Everolimus plus octreotide longacting repeatable in patients with advanced lung neuroendocrine tumors: analysis of the phase 3, randomized, placebo-controlled RADIANT-2 study. Chest 2013;143:955-62.

68. Duran I, Kortmansky J, Singh D, Hirte H, Kocha W, Goss G, Le L, Oza A, Nicklee T, Ho J, Birle D, Pond GR, Arboine D, Dancey J, Aviel-Ronen S, Tsao MS, Hedley D, Siu LL. A phase II clinical and pharmacodynamic study of temsirolimus in advanced neuroendocrine carcinomas. Br J Cancer 2006;95:1148-54.

69. Hafsi S, Pezzino FM, Candido S, Ligresti G, Spandidos DA, Soua Z, McCubrey JA, Travali S, Libra M. Gene alterations in the PI3K/ PTEN/AKT pathway as a mechanism of drug-resistance (review). Int J Oncol 2012;40:639-44.

70. Zhang S, Yu D. PI(3)king apart PTEN's role in cancer. Clin Cancer Res 2010;16:4325-30.

71. Ramaswamy S, Nakamura N, Vazquez F, Batt DB, Perera S, Roberts TM, Sellers WR. Regulation of G1 progression by the PTEN tumour suppressor protein is linked to inhibition of the phosphatidylinositol 3-kinase/Akt pathway. Proc Natl Acad Sci U S A 1999;96:2110-5.

72. Myers MP, Pass I, Batty IH, Van der Kaay J, Stolarov JP, Hemmings BA, Wigler MH, Downes CP, Tonks NK. The lipid phosphatase activity of PTEN is critical for its tumour suppressor function. Proc Natl Acad Sci U S A 1998;95:13513-8.

73. Furnari FB, Huang HJ, Cavenee WK. The phosphoinositol phosphatase activity of PTEN mediates a serum-sensitive G1 growth arrest in glioma cells. Cancer Res 1998;58:5002-8.

74. Putz U, Howitt J, Doan A, Goh CP, Low LH, Silke J, Tan SS The tumour suppressor PTEN is exported in exosomes and has phosphatase activity in recipient cells. Sci Signal 2012;5:ra70.

75. Tamura M, Gu J, Takino T, Yamada KM. Tumour suppressor PTEN inhibition of cell invasion, migration, and growth: differential involvement of focal adhesion kinase and p130Cas. Cancer Res 1999;59:442-9.

76. Kim JS, Xu X, Li H, Solomon D, Lane WS, Jin T, Waldman T. Mechanistic analysis of a DNA damage-induced, PTEN-dependent size checkpoint in human cells. Mol Cell Biol 2011;31:2756-71.

77. Wang L, Ignat A, Axiotis CA. Differential expression of the PTEN tumour suppressor protein in fetal and adult neuroendocrine tissues and tumours: progressive loss of PTEN expression in poorly differentiated neuroendocrine neoplasms. Appl Immunohistochem 
Mol Morphol 2002;10:139-46.

78. Collaud S, Tischler V, Atanassoff A, Wiedl T, Komminoth P, Oehlschlegel C, Weder W, Soltermann A. Lung neuroendocrine tumors: correlation of ubiquitinylation 1 and sumoylation with nucleo-cytosolic partitioning of PTEN. BMC Cancer 2015;15:74.

79. Samani AA, Yakar S, LeRoith D, Brodt P. The role of the IGF system in cancer growth and metastasis: overview and recent insights. Endocr Rev 2007;28:20-47.

80. Furukawa M, Raffeld M, Mateo C, Sakamoto A, Moody TW, Ito T, Venzon DJ, Serrano J, Jensen RT. Increased expression of insulin-like growth factor I and/or its receptor in gastrinomas is associated with low curability, increased growth, and development of metastases. Clin Cancer Res 2005;11:3233-42.

81. Chaves J, Saif MW. IGF system in cancer: from bench to clinic. Anticancer Drugs 2011;22:206-12.

82. von Wichert G, Jehle PM, Hoeflich A, Koschnick S, Dralle H, Wolf E, Wiedenmann B, Boehm BO, Adler G, Seufferlein T. Insulinlike growth factor-I is an autocrine regulator of chromogranin A secretion and growth in human neuroendocrine tumor cells. Cancer Res 2000;60:4573-81.

83. Nilsson O, Wangberg B, Theodorsson E, Skottner A, Ahlman H. Presence of IGF-I in human midgut carcinoid tumours--an autocrine regulator of carcinoid tumour growth? Int $J$ Cancer 1992;51:195-203.

84. Nilsson O, Wangberg B, McRae A, Dahlstrom A, Ahlman H. Growth factors and carcinoid tumours. Acta Oncol 1993;32:115-24.

85. Wulbrand U, Wied M, Zöfel P, Göke B, Arnold R, Fehmann H. Growth factor receptor expression in human gastroenteropancreatic neuroendocrine tumours. Eur J Clin Invest 1998;28:1038-49.

86. Höpfner M, Baradari V, Huether A, Schöfl C, Scherübl H. The insulin-like growth factor receptor 1 is a promising target for novel treatment approaches in neuroendocrine gastrointestinal tumours. Endocr Relat Cancer 2006;13:135-49.

87. Vitale L, Lenzi L, Huntsman SA, Canaider S, Frabetti F, Casadei R, Facchin F, Carinci P, Zannotti M, Coppola D, Strippoli P. Differential expression of alternatively spliced mRNA forms of the insulin-like growth factor 1 receptor in human neuroendocrine tumours. Oncol Rep 2006;15:1249-56.

88. Richardson PG, Mitsiades CS, Laubach JP, Lonial S, Chanan-Khan AA, Anderson KC. Inhibition of heat shock protein 90 (HSP90) as a therapeutic strategy for the treatment of myeloma and other cancers. Br J Haematol 2011;152:367-79.

89. Gloesenkamp C, Nitzsche B, Lim AR, Normant E, Vosburgh E, Schrader M, Ocker M, Scherübl H, Höpfner M. Heat shock protein 90 is a promising target for effective growth inhibition of gastrointestinal neuroendocrine tumours. Int $J$ Oncol 2012;40:1659-67.

90. Gilbert JA, Adhikari LJ, Lloyd RV, Halfdanarson TR, Muders MH, Ames MM. Molecular markers for novel therapeutic strategies in pancreatic endocrine tumors. Pancreas 2013;42:411-21.

91. Froesch ER, Schmid C, Schwander J, Zapf J. Actions of insulin-like growth factors. Ann Rev Physiol 1985;47:443-67.

92. Schoenle E, Zapf J, Humbel RE, Froesch ER. Insulin-like growth factor I stimulates growth of hypophysectomised rats. Nature 1982;296:252-3.

93. Adams SO, Nissley SP, Handwerger S, Rechler MM. Developmental patterns of insulin-like growth factor-I and -II synthesis and regulation in rat fibroblasts. Nature 1983;302:150-3.

94. Shi Y, Yan H, Frost P, Gera J, Lichtenstein A. Mammalian target of rapamycin inhibitors activate the AKT kinase in multiple myeloma cells by up-regulating the insulin-like growth factor receptor/insulin receptor substrate-1/phosphatidylinositol 3-kinase cascade. Mol Cancer Ther 2005;4:1533-40.

95. Wan X, Harkavy B, Shen N, Grohar P, Helman LJ. Rapamycin induces feedback activation of Akt signaling through an IGF-1Rdependent mechanism. Oncogene 2007;26:1932-40.

96. O'Reilly KE, Rojo F, She QB, Solit D, Mills GB, Smith D, Lane H, Hofmann F, Hicklin DJ, Ludwig DL, Baselga J, Rosen N. mTOR inhibition induces upstream receptor tyrosine kinase signaling and activates Akt. Cancer Res 2006;66:1500-8.

97. Rowinsky EK, Youssoufian H, Tonra JR, Solomon P, Burtrum D, Ludwig DL. IMC-A12, a human IgG1 monoclonal antibody to the insulin-like growth factor I receptor. Clin Cancer Res 2007; 13:5549-55s.

98. Anthony LB, Loehrer PJ, Leong S, Shah MH, Safran H, Senzer NN, Zojwalla NJ, Youssoufian H. Phase II study of cixutumumab (IMC-A12) plus depot octreotide for patients with metastatic carcinoid or islet cell carcinoma. J Clin Oncol 2010;28;15s.

99. Naing A, Kurzrock R, Burger A, Gupta S, Lei X, Busaidy N, Hong D, Chen HX, Doyle LA, Heilbrun LK, Rohren E, Ng C, Chandhasin C, LoRusso P. Phase I Trial of Cixutumumab Combined with Temsirolimus in Patients with Advanced Cancer. Clin Cancer Res 2011;17:6052-60.

100. Rothenberg ML, Tolcher AW, Sarantopoulos J, Rodon J, Friberg G, Deng H, McCafferey I, Hwang Y, Puzanov I. AMG 479 monotherapy to treat patients with advanced GI carcinoid tumors: a subset analysis from the first-in-human study. Presented at the ASCO Gastrointestinal Cancers Symposium, San Francisco, January 2009

101. Strosberg JR, Chan JA, Ryan DP, Meyerhardt JA, Fuchs CS, Abrams T, Regan E, Brady R, Weber J, Campos T, Kvols LK, Kulke MH. A multi-institutional, phase II open-label study of ganitumab (AMG 479) in advanced carcinoid and pancreatic neuroendocrine tumors. Endocr Relat Cancer 2013;20:383-90.

102. Sartelet H, Decaussin M, Devouassoux G. Nawrocki-Raby B, Brichon PY, Brambilla C, Brambilla E. Expression of vascular endothelial growth factor (VEGF) and its receptors (VEGF-R1 [Flt1] and VEGF-R2 [KDR/Flk-1]) in tumor lets and in neuroendocrine cell hyperplasia of the lung. Hum Pathol 2004;35:1210-7.

103. Bertino EM, Confer PD, Colonna JE, Ross P, Otterson GA. Pulmonary neuroendocrine/carcinoid tumors. Cancer 2009;115:4434-41.

104. Folkman J. Angiogenesis in cancer, vascular, rheumatoid and other disease. Nat Med 1995;1:27-31.

105. Berger DP, Herbstritt L, Dengler WA, Marmé D, Mertelsmann R, Fiebig HH. Vascular endothelial growth factor (VEGF) mRNA expression in human tumour models of different histologies. Ann Oncol 1995;6:817-25

106. Lawnicka H, Stepieñ H, Wyczółkowska J, Kolago B, KunertRadek J, Komorowski J. Effect of somatostatin and octreotide on proliferation and vascular endothelial growth factor secretion from murine endothelial cell line (HECa10) culture. Biochem Biophys Res Commun 2000;268:567-71.

107. Kuo CJ, Farnebo F, Yu EY, Christofferson R, Swearingen RA, Carter R, von Recum HA, Yuan J, Kamihara J, Flynn E, D’Amato R, Folkman J, Mulligan RC. Comparative evaluation of the antitumour activity of antiangiogenic proteins delivered by gene transfer. Proc Natl Acad Sci U S A 2001;98:4605-10.

108. Matsumoto T, Claesson-Welsh L. VEGF receptor signal transduction. Sci STKE 2001;2001:re21.

109. Klagsbrun M, Takashima S, Mamluk R. The role of neuropilin in vascular and tumour biology. Adv Exp Med Biol 2002;515:33-48.

110. Ferrara N, Gerber HP, LeCouter J. The biology of VEGF and its receptors. Nat Med 2003;9:669-76.

111. Treiber G, Wex T, Röcken C, Fostitsch P, Malfertheiner P. Impact of biomarkers on disease survival and progression in patients treated with octreotide for advanced hepatocellular carcinoma. J Cancer Res Clin Oncol 2006;132:699-708.

112. Dimitroulopoulos D, Xinopoulos D, Tsamakidis K, Zisimopoulos A, Andriotis E, Panagiotakos D, Fotopoulou A, Chrysohoou C, Bazinis A, Daskalopoulou D, Paraskevas E. Long acting octreotide in the treatment of advanced hepatocellular cancer and overexpression of somatostatin receptors: randomized placebo-controlled trial. World J Gastroenterol 2007;13:3164-70

113. Ho QT, Kuo CJ. Vascular endothelial growth factor: Biology and therapeutic applications. Int J Biochem Cell Biol 2007;39:1349-57.

114. O'Farrell AM, Abrams TJ, Yuen HA, Ngai TJ, Louie SG, Yee KW, Wong LM, Hong W, Lee LB, Town A, Smolich BD, Manning WC, 
Murray LJ, Heinrich MC, Cherrington JM. SU11248 is a novel FLT3 tyrosine kinase inhibitor with potent activity in vitro and in vivo. Blood 2003;101:3597-605.

115. Faivre S, Delbaldo C, Vera K, Robert C, Lozahic S, Lassau N, Bello C, Deprimo S, Brega N, Massimini G, Armand JP, Scigalla P, Raymond E. Safety, pharmacokinetic, and antitumor activity of SU11248, a novel oral multitarget tyrosine kinase inhibitor, in patients with cancer. $J$ Clin Oncol 2006;24:25-35.

116. Kulke MH, Lenz HJ, Meropol NJ, Posey J, Ryan DP, Picus J, Bergsland E, Stuart K, Tye L, Huang X, Li JZ, Baum CM, Fuchs CS. Activity of sunitinib in patients with advanced neuroendocrine tumours. J Clin Oncol 2008;26:3403-10.

117. Raymond E, Dahan L, Raoul JL, Bang YJ, Borbath I, LombardBohas C, Valle J, Metrakos P, Smith D, Vinik A, Chen JS, Hörsch D, Hammel P, Wiedenmann B, Van Cutsem E, Patyna S, Lu DR, Blanckmeister C, Chao R, Ruszniewski P. Sunitinib malate for the treatment of pancreatic neuroendocrine tumours. $N$ Engl $J$ Med 2011;364:501-13.

118. Yao JC, Phan AT, Hoff PM, Chen HX, Charnsangavej C, Yeung SC, Hess K, Ng C, Abbruzzese JL, Ajani JA. Targeting vascular endothelial growth factor in advanced carcinoid tumour: a random assignment phase II study of depot octreotide with bevacizumab and pegylated interferon alpha-2b. J Clin Oncol 2008;26,1316-23.

119. Faivre S, Sablin MP, Dreyer C, Raymond E. Novel anticancer agents in clinical trials for well-differentiated neuroendocrine tumours. Endocrinol Metab Clin North Am 2010;39:811-26.

120. Chan JA, Stuart K, Earle CC, Clark JW, Bhargava P, Miksad R, Blaszkowsky L, Enzinger PC, Meyerhardt JA, Zheng H, Fuchs CS, Kulke MH. Prospective Study of bevacizumab plus temozolomide in patients with advanced neuroendocrine tumors. J Clin Oncol 2012;1 30:2963-8.

121. Yao JC, Phan AT, Fogleman D, Ng CS, Jacobs CB, Dagohoy CD, Leary C, Hess KR. Randomized run-in study of bevacizumab (B) and everolimus (E) in low- to intermediate-grade neuroendocrine tumors (LGNETs) using perfusion CT as functional biomarker. $J$ Clin Oncol 2010;28 suppl 15:abstr 4002.

122. Sonpavde G, Hutson TE. Pazopanib: a novel multitargeted tyrosine kinase inhibitor. Curr Oncol Rep 2007;9:115-9.

123. Ahn HK, Choi JY, Kim KM, Kim H, Choi SH, Park SH, Park JO, Lim HY, Kang WK, Lee J, Park YS. Phase II study of pazopanib monotherapy in metastatic gastroenteropancreatic neuroendocrine tumours. Br J Cancer 2013;109:1414-9.

124. Phan AT, Yao JC, Fogelman DR, Hess KR, Ng CS, Bullock SA, Malinowski P, Regan E, Kulke M. A prospective, multi-institutional phase II study of GW786034 (pazopanib) and depot octreotide (sandostatin LAR) in advanced low-grade neuroendocrine carcinoma (LGNEC). Proc Am Soc Clin Oncol 2010;28:abstr 4001.

125. Phan AT, Halperin DM, Chan JA, Hess KR, Malinowski P, Regan E, Ng CS, Yao JC, Kulke MH. Pazopanib and depot octreotide in advanced, well-differentiated neuroendocrine tumours: a multicentre, single-group, phase 2 study. Lancet Oncol 2015;16:695-703.

126. Wilhelm SM, Carter C, Tang L, Wilkie D, McNabola A, Rong H, Chen C, Zhang X, Vincent P, McHugh M, Cao Y, Shujath J, Gawlak S, Eveleigh D, Rowley B, Liu L, Adnane L, Lynch M, Auclair D, Taylor I, Gedrich R, Voznesensky A, Riedl B, Post LE, Bollag G, Trail PA. BAY 43-9006 exhibits broad spectrum oral antitumour activity and targets the RAF/MEK/ERK pathway and receptor tyrosine kinases involved in tumour progression and angiogenesis.
Cancer Res 2004;64:7099-109.

127. Wilhelm SM, Dumas J, Adnane L, Lynch M, Carter CA, Schütz G, Thierauch KH, Zopf D. Regorafenib (BAY 73-4506): a new oral multikinase inhibitor of angiogenic, stromal and oncogenic receptor tyrosine kinases with potent preclinical antitumour activity. Int $J$ Cancer 2011;129:245-55.

128. Bill R, Fagiani E, Zumsteg A, Antoniadis H, Johansson D, Haefliger S, Albrecht I, Hilberg F, Christofori G. Nintedanib Is a Highly Effective Therapeutic for Neuroendocrine Carcinoma of the Pancreas (PNET) in the Rip1Tag2 Transgenic Mouse Model. Clin Cancer Res 2015;21:4856-67.

129. Bago-Horvath Z, Sieghart W, Grusch M, Lackner A, Hayden H, Pirker C, Komina O, Węsierska-Gądek J, Haitel A, Filipits M, Berger W, Schmid K. Synergistic effects of erlotinib and everolimus on bronchial carcinoids and large-cell neuroendocrine carcinomas with activated EGFR/AKT/ mTOR pathway. Neuroendocrinology 2012;96:228-37.

130. Shah T, Hochhauser D, Frow R, Quaglia A, Dhillon AP, Caplin ME. Epidermal growth factor receptor expression and activation in neuroendocrine tumours. $J$ Neuroendocrinol 2006; 18:355-60.

131. Papouchado B, Erickson LA, Rohlinger AL, Hobday TJ, Erlichman C, Ames MM, Lloyd RV. Epidermal growth factor receptor and activated epidermal growth factor receptor expression in gastrointestinal carcinoids and pancreatic endocrine carcinomas. Mod Pathol 2005;18:1329-35.

132. Srivastava A, Alexander J, Lomakin I, Dayal Y. Immunohistochemical expression of transforming growth factor alpha and epidermal growth factor receptor in pancreatic endocrine tumours. Hum Pathol 2001;32:1184-9.

133. Nilsson O, Wangberg B, Kolby L, Schultz GS, Ahlman H. Expression of transforming growth factor alpha and its receptor in human neuroendocrine tumours. Int J Cancer 1995;60:645-51.

134. Krishnamurthy S, Dayal Y. Immunohistochemical expression of transforming growth factor alpha and epidermal growth factor receptor in gastrointestinal carcinoids. Am J Surg Pathol 1997;21:327-33.

135. Shimizu T, Tanaka S, Haruma K, Kitadai Y, Yoshihara M, Sumii K, Kajiyama G, Shimamoto F. Growth characteristics of rectal carcinoid tumours. Oncology 2000;59:229-37.

136. Hobday TJ, Holen K, Donehower RC, Camoriano J, Kim G, Picus J, Philip P, Lloyd R, Mahoney M, Erlichman C. A phase II trial of gefitinib in patients (pts) with progressive metastatic neuroendocrine tumours (NET): a phase II consortium (P2C) study. J Clin Oncol 2006;24:189S. Available from: URL: http://meeting.ascopubs.org/ cgi/content/abstract/24/18_suppl/4043.

137. Modlin IM, Shapiro MD, Kidd M. Carcinoid tumor and fibrosis: an association with no explanation. Am J Gastroenterol 2004;99:2466-78

138. Yao JC, Zhang JX, Rashid A, Yeung SC, Szklaruk J, Hess K, Xie $\mathrm{K}$, Ellis L, Abbruzzese JL, Ajani JA. Clinical and in vitro studies of imatinib in advanced carcinoid tumours. Clin Cancer Res 2007; $13: 234-40$.

139. Lankat-Buttgereit B, Hörsch D, Barth P, Arnold R, Blöcker S, Göke R. Effects of the tyrosine kinase inhibitor imatinib on neuroendocrine tumour cell growth. Digestion 2005;71:131-40.

140. Schott M, Feldkamp J, Lettmann M, Simon D, Scherbaum WA, Seissler J. Dendritic cell immunotherapy in a neuroendocrine pancreas carcinoma. Clin Endocrinol (Oxf) 2001;55:271-7. 